\title{
Ownership Structure, Bank Stability and the Financial Performance of Commercial Banks in South Sudan
}

\author{
Bak Barnaba Chol ${ }^{\text {a }}$, Elizabeth Kalunda Nthambi ${ }^{\text {b }}$, Joseph Kamau \\ a,b,c United States International University, Kenya \\ hiramkirm@gmail.com
}

\begin{abstract}
Since independence in 2011, the Republic of South Sudan has witnessed growth in the financial systems and the overall economy. This has led to growth in the number of financial institutions in the country. There is however minimal research on their overall performance. Hence the current research sought to determine the effect of ownership structure, bank stability and the financial performance of commercial banks in South Sudan. The population for the study was all the 29 commercial banks in South Sudan. Secondary data was collected for the period 20122017 from audited annual financial reports of individual banks and the Central Bank of South Sudan reports while primary data was collected by the use of a semi-structured questionnaire. Collected data was edited, sorted and coded into SPSS 23 for subsequent data analysis using SPSS 23 statistical analysis tool. This research utilized both descriptive and inferential statistical methods in the analysis. Statistical tests to be utilized in the study included $t$-tests, $f$ test, regression models and ANOVA models. Findings of the research were presented using frequencies, percentages, means, standard deviation, correlation coefficients, charts, tables, and other statistical measures. Results of the study indicated there was a statistically significant moderating effect of ownership structure on the financial performance of commercial banks in South Sudan. This study recommends that the government should adopt better measures to safeguard public-owned commercial banks to improve their efficiency and performance.
\end{abstract}

Article Info

- Received : October 10, 2019

- Revised : December 12, 2019

- Published : January 15, 2020

- No. Pages : $1-13$

- DOI : 10.33019/ijbe.v4i1.242

- JEL : G21, G32

- Keywords : foreign ownership, private-local ownership, public ownership, joint venture, financial performance

\section{Introduction}

The main aim of commercial banks is to register better performance through sustained profitability and growth (Pearce \& Robinson, 2011). However, attempts to realize such successes, are often affected by multiple operating market conditions such as the level of competition, stakeholders management, political landscape, business legal regime, the cost of doing business, new innovative products, internal organizational structure, emerging technologies, and effects of globalization (Kotler \& Armstrong, 2013). Banking is a critical sector in an economy and its performance should be monitored closely to safeguard the interest 
of a countries economy ( $\mathrm{Al}$ Mamun, 2013). Banks are catalysts of economic growth through the provision of financial services to the citizenry. Profitable performance of banks translates to economic growth and stability of an economy through financial sector stability (Beck, Hesse, Kick, \& Westernhagen, 2009). Also, good performance of commercial banks is a key factor for a robust financial system which can withstand volatility and shocks in the economy; however, poor performance can contribute to major financial crisis especially within emerging economies (Nimalathasan, 2008).

In recognition of the vital role the banking sector plays in economic development, there has been an upsurge of initiatives by Central Banks and Reserve Banks alongside other institutions worldwide such as the Basel Committee on Banking and Supervision and OECD to provide governance principles with a view of enhancing management and performance of this important sector. Most of these initiatives have prominently featured in developed nations such as U.S.A., United Kingdom, Germany, Canada, and France among others with South Africa taking a lead in addressing corporate governance issues among developing nations in Africa (Elewechi, 2007). According to World Bank (2013), there were over 10,000 operational commercial banks spread across the globe by December 2012. Out of these, $60 \%$ were located in developing countries which account for $80 \%$ of the total world population. Africa accounted for about $12 \%$ of this total, Asian country having 70\%, and Latin America accounted for 17\%. Ndoka, Islami, and Shima, (2017) acknowledged that commercial banks across the globe have been reeling from the chaos that erupted in the financial sector during the global financial crisis. This coupled with increasing internal pressures this has posed tremendous challenges on the financial soundness of commercial banks. Bekele (2015) further notes that poor financial risk management practices are lack of adequate internal controls have negatively impacted the financial performance of commercial banks. Jima and Raju (2015) concluded that external environment has been one of the main challenges that have been affecting the banking sector operations within commercial banks in East Africa.

In a study on the performance of commercial banks in Sri Lanka; Seelanatha (2010) indicated that the performance of commercial banks was dependent on the level of the institutional efficiency. On the other hand, Jaber and Al-Khawaldeh (2014) sought to examine the factors contributing to positive profitability within the banks in Jordan. Findings from the study indicated that external factors such as inflation, Gross Domestic Product and the capital market capitalization have a strong impact on the performance of commercial banks. Nasserinia, Ariff and Fan-Fah (2014) studied how internal factors affect the performance of commercial banks in Japan. Findings from the study indicated that there was a negative relationship between capital adequacy, credit risk and performance of banks while management efficiency, liquidity and asset quality had a positive influence on the performance of commercial banks.

Evidence from developing economies (Yener \& David, 2008); indicate that a stable banking system is integral to promoting economic growth and development of institutions within the country. Abera (2012) indicates that internal bank-specific factors are key to fostering the stability of commercial banking institutions. Beck, Hesse, Kick, and Westernhagen (2009) concluded that the stability of financial institutions is a key indicator of a well functioning economic system. Fang, Hasan, and Marton, (2014) indicate that a sound and stable financial sector in transition economies is essential for promoting institutional development and firm performance. According to the IMF (2017), Article IV consultation press report; the republic of South Sudan has been experiencing macroeconomic imbalances which have dampened the ongoing macroeconomic stability endeavours and the structuring of the country's financial sector. The report further indicates that through regulatory mechanisms commercial banks have 
been required to adhere to statutory requirements on minimum capital which has reduced vulnerabilities in the banking sector. However, despite setting up the minimum capital requirements for both foreign-owned and locally-owned banks only about half of the banks have been able to meet the requirements. The banking industry in the country is populated by regional banks mostly from Kenya which have been achieving relatively better performance than indigenous banking institutions in the country (FSNWG, 2015). The current study sought to examine how the ownership structure and bank stability affect the financial performance of commercial banks.

\section{Literature Review}

Sharma and Arora (2016) conducted a study Performance of Indian Banks: A Camel Model Approach. The study utilized data from 8 public sector banks and 7 private sector banks. The study further adopted a descriptive research design with only secondary data being utilized. The results of the study revealed that based on the CAMEL model indicators private banks were better ranked than public sector banks. In an IMF working paper, Robert, Maria, Martinez, and Jeanne, (2017); examined the bank ownership; trends and implications within countries across the world. The findings of the review indicated that foreign-owned banks are more performing than domestically owned banks within developing countries. However, due to imported external shocks by foreign banks the foreign-owned banks may not be always better performing. The findings also indicated that government-owned banks had fewer benefits within developing countries due to corruption, bureaucracy and poor reform processes.

James and Shaban (2017) examined the effects of ownership change on bank performance and risk exposure: Evidence from Indonesia. The study sampled 60 commercial banks in Indonesia and utilized panel data for the period 2005-2012. The study utilized multiple linear regression methods to estimate the effects of ownership on the performance and risk exposure of commercial banks. Result of the regression indicated that state-owned banks tend to be less profitable and more exposed to risk than private and foreign banks. The findings of the study further indicated that Non-regional foreign acquisition is associated with a reduction in risk exposure. Acquisition by regional foreign investors is associated with performance gains. Akhigbe, McNulty, and Stevenson (2017) conducted a study exploring whether the form of ownership affects firm performance? Evidence from US bank profit efficiency before and during the financial crisis. The study utilized panel data to examine the differences between privately held and publically traded bank holding companies (BHCs). The findings indicated that there were small differences between privately held and publicly held banking companies during the pre-crisis period however during the crisis period there were no statistically significant differences.

Garba and Mohamed (2017) conducted a study examining the impact of foreign ownership on the going-concern of Nigerian Listed Banks. Data was collected from the annual reports and financial statement of 15 listed commercial banks from 2011 to 2015. The analysis of the collected data was conducted using descriptive statistics, Pearson correlation, along with fixedeffect and random-effect generalized least square (GLS) regression techniques. The results of the analysis indicated that there was a significant positive relationship between foreign ownership and going concern of listed Banks in Nigeria.

Ermias (2016) examined the financial performance of private commercial banks in Ethiopia using a CAMEL approach. The research utilized a fixed least square method for estimation for the considered banks only. The results of the study indicated that the CAMEL model aspects had a comparative influence of $67.5 \%$ of the influence on bank profitability. In another study, 
Kijjambu and Ddumba-Ssentamu (2015) examined increased foreign commercial banks and the performance of domestic commercial banks in Uganda. The study utilized descriptive statistics for the period 2000-2011 with the performance trend divided into periods. The findings of the study indicated that with increased foreign-owned commercial banks enhanced the liquidity position, deposits and interest income for domestic banks. The study findings also indicated that policy implications brought forward by foreign-owned banks enhanced the commercial banking sector development. Kiruri (2013) examined the effects of ownership structure on the bank profitability in Kenya. The study utilized data from Kenyan commercial banks for the period 2007-2011 and conducted a multiple regression model. The study found out that state ownership had a significant negative influence on the profitability of commercial banks. The study findings also indicated that foreign ownership and domestic ownership was highly correlated to positive and significant influence on bank profitability. In general, the study indicated that higher concentration of ownership and state ownership was associated with lower profitability.

\section{Research Methods}

Research philosophy refers to the assumptions and beliefs that govern the way we view the world (Saunders et al., 2007). This research was grounded on positivism research philosophy. This kind of philosophy calls for the research problem to be structured around a methodology that enabled the research to generate quantifiable observations and undertake manipulation of the data by the use of statistical methods. According to Sekaran (2003) research design is a set of decision that makes up the master plan specifying the methods and procedures for collecting and analysing the needed information. This study adopted a descriptive survey research design. Kothari (2008) indicates that the population of research represents all the items, objects or individuals who are of relevance to the research study. In the current study, the unit of analysis was the individual commercial bank organizations operating in South Sudan. There are 29 indigenous and foreign banks operating in South Sudan.

Baxter and Jack (2008) define data collection as the precise, systematic gathering of information relevant to the research sub-problems, using methods such as interviews, participant observations, focus group discussion, narratives and case histories. Secondary data was collected from government records, banks financial reports and other official publications. The secondary data was sourced from the financial year 2012-2017 to ensure that the records formalization since 2012 marked the first financial year since Independence of South Sudan was in 2011. Quantitative data were analysed using descriptive analysis and inferential analysis techniques with the help of Statistical Packages for Social Sciences (SPSS Version 23). Descriptive analysis included percentage, frequencies, means and standard deviations on the research variables. Inferential statistics will include multiple regression analysis and correlation to estimate the level of association between the research variables. The analysed data was presented using charts and tables as well as other infographics deemed appropriate.

\section{Results}

\section{Descriptive Analysis}

\section{South Sudan Banking Industry Analysis}

Study sought to establish the link between bank stability and the financial performance of commercial banks in South Sudan. The research utilized the CAMEL model as the indicators of the financial performance of commercial banks and the return on assets and return on equity as the measures of the financial performance of commercial banks. The study was conducted across 24 commercial banks in South Sudan for the period 2012-2017. From the 24 commercial 
banks, the study was able to obtain 137 observations within 6 years period the research data was collected.

\section{Capital Adequacy of Commercial Banks}

Results of the study on Table 1 below, indicates that the capital adequacy of commercial banks within South Sudan has been moderately stable as shown by a mean of 30.399 in 2012 which steadily rose to 43.8 in 2014. This further changed slightly to an average of 32.64 and fluctuated to 27.97 in 2016 and rose slightly in 2017 to an average of 30.23. The standard deviation ranges between 0.2292 and 0.3048 indicating minimal variation in the capital adequacy of commercial banks. These results are consistent with the economic outlook by IMF (2017) which indicated that there was a slight movement in the average capital adequacy across commercial banks in South Sudan.

Table 1. Capital Adequacy

\begin{tabular}{lcccccc}
\hline Year & $\mathbf{2 0 1 2}$ & $\mathbf{2 0 1 3}$ & $\mathbf{2 0 1 4}$ & $\mathbf{2 0 1 5}$ & $\mathbf{2 0 1 6}$ & $\mathbf{2 0 1 7}$ \\
\hline Mean & 30.399 & 43.15 & 43.8 & 32.64 & 27.97 & 30.23 \\
Std. Dev & 0.1961 & 0.258 & 0.2972 & 0.3048 & 0.257 & 0.2648 \\
Max & 67 & 96 & 96.5 & 93.7 & 83.1 & 76.9 \\
Min & -9 & 4.5 & -9 & -41.6 & -26 & -9.5 \\
\hline
\end{tabular}

Source: SPSS output

\section{Asset Quality of Commercial Banks}

The study sought to examine the asset quality of commercial banks within South Sudan. Asset quality was computed by Level of non-performing loans to the net of provision: Capital.

Table 2. Asset Quality

\begin{tabular}{lcccccc}
\hline Year & $\mathbf{2 0 1 2}$ & $\mathbf{2 0 1 3}$ & $\mathbf{2 0 1 4}$ & $\mathbf{2 0 1 5}$ & $\mathbf{2 0 1 6}$ & $\mathbf{2 0 1 7}$ \\
\hline Mean & 3.42 & 1.6 & 1.13 & 1.59 & 1.19 & 0.57 \\
Std. Dev & 0.0545 & 0.035 & 0.319 & 0.492 & 0.365 & 0.28 \\
Max & 15.2 & 12.5 & 12.2 & 24.2 & 16.7 & 14.3 \\
Min & 0 & 0 & 0 & 0 & 0 & 0 \\
\hline
\end{tabular}

Source: SPSS output

The findings of the study in Table 2, examined the average asset quality across commercial banks in South Sudan. The findings of the study indicated that asset quality across commercial banks stood at 3.42 in the year 2012 and decreased to 1.6 in 2013. The research results further showed that the mean average asset quality was at a 1.13 in 2014 and rose to 1.59 in 2015; which dropped in the period 2016 to 2017 as shown by an average asset quality of 1.19 and 0.57 respectively. The stability in the asset quality noted within the study period can be attributed to the fact that most commercial banks in South Sudan do not offer loans and concentrate on foreign exchange trading as indicated by the Minister of Finance Report (2014) on the performance of the banking sector in South Sudan.

\section{Management Efficiency of Commercial Banks}

The study sought to examine the management efficiency of commercial banks within South Sudan. Management efficiency was computed by Personal Expense: Non-Interest Expense.

Table 3. Management Efficiency

\begin{tabular}{lcccccc}
\hline Year & $\mathbf{2 0 1 2}$ & $\mathbf{2 0 1 3}$ & $\mathbf{2 0 1 4}$ & $\mathbf{2 0 1 5}$ & $\mathbf{2 0 1 6}$ & $\mathbf{2 0 1 7}$ \\
\hline Mean & 29.88 & 33.24 & 23.53 & 23.25 & 20.1 & 18.83 \\
Std. Dev & 0.1283 & 0.1321 & 0.959 & 1.111 & 1.505 & 1.477
\end{tabular}




\begin{tabular}{lcccccc}
\hline Year & $\mathbf{2 0 1 2}$ & $\mathbf{2 0 1 3}$ & $\mathbf{2 0 1 4}$ & $\mathbf{2 0 1 5}$ & $\mathbf{2 0 1 6}$ & $\mathbf{2 0 1 7}$ \\
\hline Max & 60.0 & 60.0 & 40.9 & 49.9 & 54.5 & 60.6 \\
Min & 12.0 & 18.0 & 3.6 & 7.4 & 0.9 & 0.9 \\
\hline Source: SPSS output & & & & &
\end{tabular}

Source: SPSS output

Research findings in Table 3, examined the management efficiency of commercial banks in South Sudan. The management efficiency within the commercial bank sector was at its highest between 2012 and 2013 with an annual average of 29.88 and 33.24 respectively. The findings of the study indicated that in 2014 commercial banks had an average management efficiency mean of 23.53; in 2015 the efficiency slightly declined to 23.25 and sharply fell to an average low of 18.83 in 2017. These results are not in line with the observations made in the investment conference proceedings by SSIC (2013) that there is a shortage of inadequate human capital which limits the quality of management personnel in commercial banks. The observation made in the current research shows that there is a positive growth in the quality of management staff which can be noted in the positive efficiency scores.

\section{Earnings of Commercial Banks}

The study sought to examine the earnings of commercial banks within South Sudan. The earnings were computed by Interest Margin: Gross Income.

Table 4. Earnings

\begin{tabular}{lcccccc}
\hline Year & $\mathbf{2 0 1 2}$ & $\mathbf{2 0 1 3}$ & $\mathbf{2 0 1 4}$ & $\mathbf{2 0 1 5}$ & $\mathbf{2 0 1 6}$ & $\mathbf{2 0 1 7}$ \\
\hline Mean & 24.5 & 16.52 & 13.55 & 17.68 & 8.98 & 16.71 \\
Std. Dev & 0.1819 & 0.176 & 1.751 & 1.678 & 1.335 & 7.7028 \\
Max & 65.0 & 74.0 & 58.8 & 51 & 44.5 & 68.4 \\
Min & 0 & 0 & 0 & -1.5 & -5.9 & 0 \\
\hline
\end{tabular}

Source: SPSS output

The study results in Table 4, examined the earnings across commercial banks in South Sudan between 2012 and 2017. The average earnings within the South Sudan commercial banks stood at 18.04 which was supported by the economic optimist post the referendum period which slightly dropped to 16.52 in the year 2013. The mean average earnings in 2014 stood at 13.55 which rose to 17.68 in 2015. The earnings across commercial banks dropped in 2016 to a low of 8.98 and sharply rose in 2017 to a high of 16.71. These results are in line with IMF (2017) Article IV report which showed that earnings within commercial banks in South Sudan have been minimal due to lack of diversification in the product and service offering.

\section{Liquidity of Commercial Banks}

The study sought to examine the liquidity of commercial banks within South Sudan. Liquidity was computed by Liquid Asset: Total Asset.

Table 5. Liquidity Descriptive

\begin{tabular}{ccccccc}
\hline Year & $\mathbf{2 0 1 2}$ & $\mathbf{2 0 1 3}$ & $\mathbf{2 0 1 4}$ & $\mathbf{2 0 1 5}$ & $\mathbf{2 0 1 6}$ & $\mathbf{2 0 1 7}$ \\
\hline Mean & 78.75 & 74.64 & 71.96 & 71.41 & 69.33 & 71.48 \\
Std. Dev & 0.1332 & 0.1199 & 0.12929 & 0.1306 & 0.198 & 0.2261 \\
Max & 96 & 96 & 97.4 & 94.7 & 97.9 & 98.1 \\
Min & 54.0 & 49.5 & 45.4 & 45 & 18.3 & 12.6 \\
\hline
\end{tabular}

Source: SPSS output

The study also sought to examine the liquidity of commercial banks in South Sudan. The results in Table 5 indicated high liquidity levels across commercial banks as shown by an average mean of 78.75 in 2012 which dropped to 74.64 and 71.96 percentage points in 2013 and 2014 
respectively. The findings of the study showed a sharp decrease in liquidity to 69.33 in FY 2016 and slightly rose to 71.48 in 2017. This agrees with IMF (2017) report that shows liquidity has been decreasing within the period in the examination.

\section{Financial Performance of Commercial Banks}

The study sought to examine the financial performance of commercial banks within South Sudan. The financial performance of commercial banks was assessed by both ROA (Net Income/Average Assets) and ROE (Net Income/Average Capital).

Table 6. Financial Performance

\begin{tabular}{lcccccc}
\hline Year & $\mathbf{2 0 1 2}$ & $\mathbf{2 0 1 3}$ & $\mathbf{2 0 1 4}$ & $\mathbf{2 0 1 5}$ & $\mathbf{2 0 1 6}$ & $\mathbf{2 0 1 7}$ \\
\hline \multicolumn{7}{c}{ ROA } \\
\hline Mean & 5.17 & 8.69 & -1.67 & -0.57 & 2.59 & -26.23 \\
Std. Dev & 0.126 & 0.0739 & 0.1293 & 0.0659 & 0.1872 & 0.99 \\
Max & 28 & 21 & 39.2 & 10.8 & 81.6 & 63 \\
Min & -16.00 & -10.0 & -23.4 & -20 & -20.3 & -484.9 \\
\hline \multicolumn{7}{c}{ ROE } \\
\hline Mean & 46.25 & 29.23 & 0.64 & 1.96 & 24.35 & 4.58 \\
Std. Dev & 0.5378 & 0.3406 & 0.7024 & 0.36 & 1.6498 & 1.2064 \\
Max & 212 & 112 & 101.6 & 116.8 & 762.9 & 274.9 \\
Min & -20.0 & -24.0 & -276.1 & -77.1 & -288.1 & -389.9 \\
\hline
\end{tabular}

Source: SPSS output

The study further examined the financial performance of commercial banks in terms of Return on Assets (ROA) and the Return on Equity (ROE) as shown in Table 6. The results of the study showed that in the six-year period under review the highest return on Asset in the period under review was noted in 2013 at 8.69 while the lowest return on assets was attained in 2017 at 26.23 and in the year 2014 at -1.67 . The performance only stabilized to 2.59 average in the year 2016. This erratic financial performance noted in the study is consistent with industry reports which indicated that volatility and structural imbalances in the South Sudan economy have ripple effects on the financial sector performance (IMF, 2017). The results of the study also indicated moderately high positive performance in terms of return on equity as noted by the mean average of 46.25 in the financial year 2012, which slightly dropped to 29.23 in the FY 2013. In general, the return on equity across the commercial bank sector was largely stabilized across the sector with a positive return of 4.58 across commercial banks. This largely shows that there is a potential positive outlook for investors as noted by the positive return on equity average performance.

\section{Ownership Structure in Commercial Banks}

The study further sought to examine the commercial bank ownership structure in South Sudan. This was examined by the ownership category presented by the central bank of South Sudan. In the current study, ownership was assessed based on the composition of major shareholders who control the board and the decision making across individual commercial banks within South Sudan. The regulator categorizes banks into Joint Venture, Private local owned, Public owned and foreign-owned. The findings of the study indicated that the majority of the commercial banks 38\% ( $n=9) 48$ observations ( 6 of the banks were not in operation in 2012) were from Joint Ventures, 29\% $(n=7) 42$ observations were foreign-owned, 25\% ( $n=6) 36$ observations were private-local owned respectively while only $8 \%(n=2) 11$ observations were from public-owned commercial banks (One of the banks was not in operation in 2012). This indicates that the commercial banking sector within South Sudan is predominantly controlled 
by foreign and local investors with minimal government-owned banks in the sector as shown in Figure 1 below.

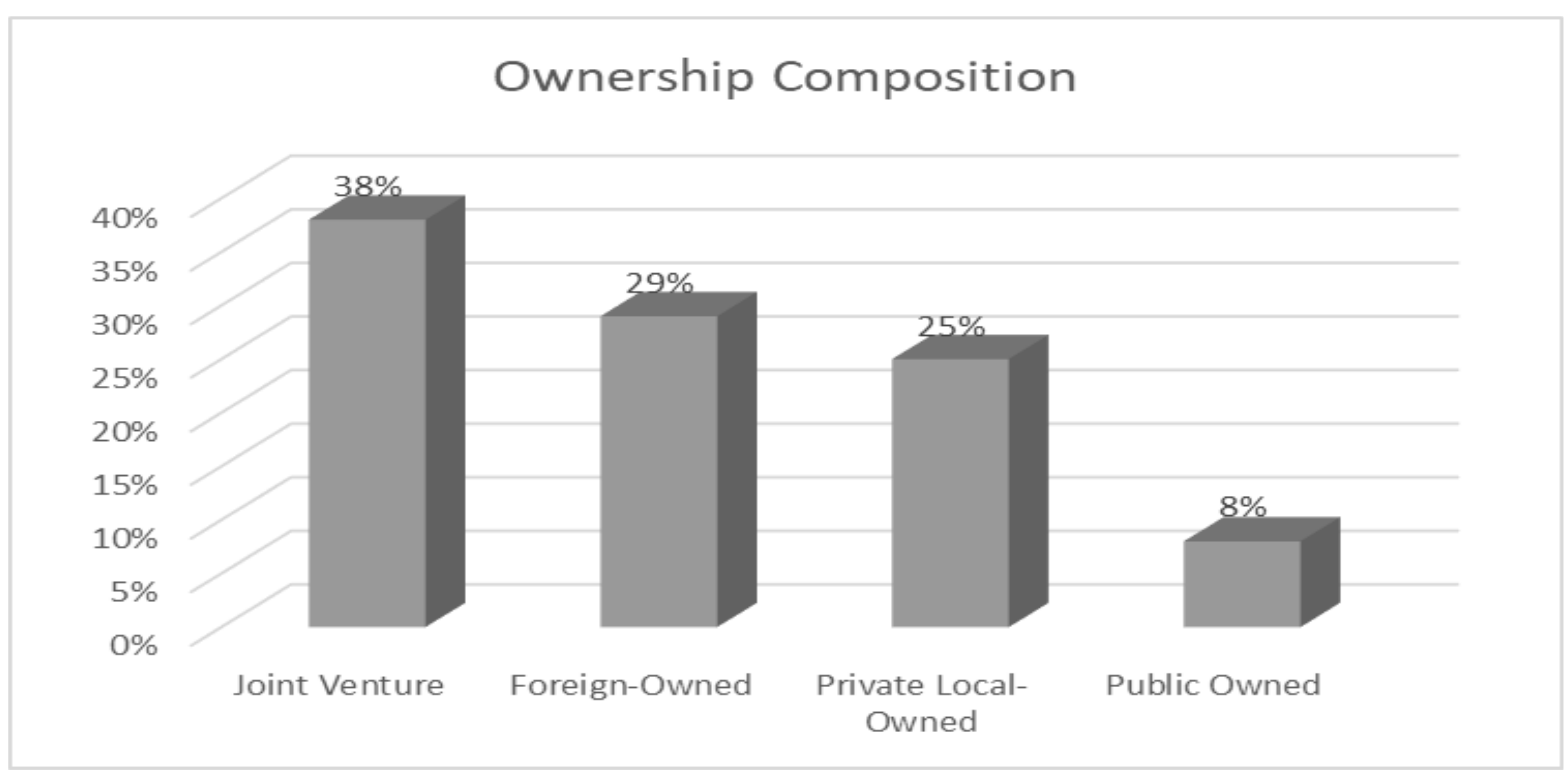

Source: Data analysis

Figure 1. Ownership Structure Distribution

\section{Inferential Analysis}

\section{Regression Results}

The main objective of the research was to examine the effect of bank stability on the financial performance of commercial banks in South Sudan. Regression summary results indicated below:

Table 7. Regression Model Summary

\begin{tabular}{lcccc}
\hline Model & $\mathrm{R}$ & $\mathrm{R}$ Square & Adjusted R Square & $\begin{array}{c}\text { Std. Error of the } \\
\text { Estimate }\end{array}$ \\
\hline 1 & $.734^{\mathrm{a}}$ & .539 & .525 & 1.83089 \\
\hline
\end{tabular}

a. Predictors: (Constant), CAMEL

Source: SPSS output

Study sought to estimate the relationship between bank stability and the financial performance of South Sudan. The results of regression analysis indicated that 53.9\% variation in the financial performance of the banks can be explained by the CAMEL model indicators $\mathrm{R}^{2}=.539$ as shown in Table 7. These results are in agreement with (Bekele, 2015; Kabir \& Dey, 2014) who indicated that CAMEL model components can explain the financial performance of commercial banks.

Table 8. ANOVA for Bank Stability and Financial Performance

\begin{tabular}{llccccc}
\hline Model & & Sum of Squares & df & Mean Square & F & Sig. \\
\hline 1 & Regression & 395.280 & 1 & 131.70 & 39.306 & $.000^{\mathrm{a}}$ \\
& Residual & 338.567 & 4 & 3.352 & & \\
& Total & 733.848 & 5 & & & \\
\hline
\end{tabular}

a. Dependent Variable: Financial Performance

Source: SPSS output

From the ANOVA model, the study found out that F- (critical f; 1.162) $=39.306$, sig $=.000$ indicating that the research model was statistically significant in indicating there is a positive 
and significant effect of bank stability on the financial performance of Commercial Banks. These findings are in agreement with previous work by (Mohiuddin, 2014; Tripathi, Meghani, \& Mahajan, 2014) who indicated there is a statistically significant relationship between the CAMEL model indicators and the financial performance of commercial banks.

Table 9. Regression Coefficients for Bank Stability and Financial Performance

\begin{tabular}{llccccc}
\hline & & \multicolumn{2}{c}{ Unstandardized } & \multicolumn{2}{c}{ Standardized } \\
Coefficients & Coefficients & & \\
Model & & $\mathrm{B}$ & Std. Error & Beta & $\mathrm{t}$ & Sig. \\
\hline 1 & (Constant) & 9.370 & 3.215 & & 2.915 & .006 \\
& CAMEL & .583 & .091 & .637 & 5.291 & .000 \\
\hline
\end{tabular}

a. Dependent Variable: Financial Performance

Source: SPSS output

Results above on Table 10, indicate a beta value $(\beta)=.583$ and is significantly different from 0 since the p-value $.000<.005$. This indicates that there is a statistically significant positive effect of bank stability on the financial performance of commercial banks. A unit change in bank stability will result in a .583 unit change in the financial performance of commercial banks in South Sudan.

\section{Tests for Moderation}

\section{Moderating Effect of Joint Venture Ownership on Bank Stability and Financial Performance}

Study runs a regression analysis to determine the moderating effect of joint venture ownership structure on the relationship between bank stability and the financial performance of commercial banks. The equation for the interaction was;

$$
\mathbf{Y}=\boldsymbol{\beta}_{\mathbf{0}}+\boldsymbol{\beta}_{1} \text { (Joint Venture } * \text { Bank Stability) }+\boldsymbol{\beta}_{\mathbf{2}} \text { (Joint Venture Ownership) }+\boldsymbol{\varepsilon}
$$

Table 10. Model Summary of Joint Venture Ownership Structure and Bank Stability

\begin{tabular}{lcccc}
\hline Model & R & R Square & Adjusted R Square & $\begin{array}{c}\text { Std. Error of the } \\
\text { Estimate }\end{array}$ \\
\hline Without & & & & \\
Moderator & $.734^{\mathrm{a}}$ & .539 & .525 & 1.83089 \\
With Moderator & $.773^{\mathrm{b}}$ & .598 & .578 & 2.09871 \\
\hline
\end{tabular}

a. Predictors: (Constant), CAMEL

b. Predictors: (Constant), CAMEL, Joint Ownership Structure

Source: SPSS output

In line with the above results the regression model summary indicates that bank stability without the moderating variable explains $53.9 \%\left(\mathrm{R}^{2}=.539\right)$ variations in the financial performance of commercial banks. With the moderating variable factored in the effect improves to $59.8 \%\left(\mathrm{R}^{2}=.598\right)$. This implies that the joint ownership structure has a positive effect on the relationship between bank stability and the financial performance of commercial banks in South Sudan. Lawrence (2017) pointed out that the consolidation of commercial banks into larger ventures was positively related to the increased financial performance of commercial banks.

Table 11. ANOVA Summary for Joint Venture Ownership Structure and Bank Stability

\begin{tabular}{lcccccc}
\hline Model & & Sum of Squares & df & Mean Square & F & Sig. \\
\hline & Regression & 395.280 & 1 & 131.70 & 39.306 & $.000^{\mathrm{a}}$
\end{tabular}




\begin{tabular}{llccccc}
\hline Model & & Sum of Squares & df & Mean Square & F & Sig. \\
\hline Without & Residual & 338.567 & 4 & 3.352 & & \\
moderator & Total & 733.848 & 5 & & & \\
With & Regression & 362.002 & 1 & 131.001 & 29.476 & $.000^{\mathrm{b}}$ \\
Moderator & Residual & 371.846 & 2 & 4.405 & & \\
& Total & 733.848 & 3 & & & \\
\hline
\end{tabular}

a. Dependent Variable: Financial Performance

b. Predictors: (Constant), CAMEL, Joint Ownership Structure

Source: SPSS output

Results of the ANOVA summary on Table 11 sought to examine the statistical significance of the moderating effect of joint ownership structure on the relationship between bank stability and the financial performance of the commercial banks. The F-statistic with the moderator variable was 29.476 which is greater than the f-critical value. The significance of the model was $p=.000<.05$. This shows that the coefficients in the model were not equal to zero and the model was fit.

Table 12. Regression Coefficient for Joint Venture Ownership and Bank Stability

\begin{tabular}{|c|c|c|c|c|c|c|}
\hline \multirow{2}{*}{\multicolumn{2}{|c|}{ Model }} & \multicolumn{2}{|c|}{$\begin{array}{c}\text { Unstandardized } \\
\text { Coefficients }\end{array}$} & \multirow{2}{*}{$\begin{array}{c}\text { Standardized } \\
\text { Coefficients } \\
\text { Beta }\end{array}$} & \multirow[b]{2}{*}{$\mathrm{t}$} & \multirow[b]{2}{*}{ Sig. } \\
\hline & & B & Std. Error & & & \\
\hline \multirow[t]{2}{*}{1} & (Constant) & 9.370 & 3.215 & & 2.915 & .006 \\
\hline & CAMEL & .583 & .091 & .637 & 5.291 & .000 \\
\hline \multirow[t]{3}{*}{2} & (Constant) & 4.749 & 2.911 & & 1.631 & .111 \\
\hline & CAMEL & .035 & .190 & .029 & .183 & .856 \\
\hline & $\begin{array}{l}\text { Joint Venture } \\
\text { Ownership }\end{array}$ & .950 & .199 & .751 & 4.767 & .000 \\
\hline
\end{tabular}

a. Dependent Variable: Financial Performance

Source: SPSS output

Findings of the study in Table 12, showed regression coefficients results for the moderating effect of joint venture ownership on the relationship between bank stability and financial performance. The coefficient of the interaction was .950 with a p-value of $.000<.005$. With the above significance in the coefficient of joint venture ownership bank stability, this implied that joint venture ownership significantly moderated the relationship between bank stability and financial performance of commercial banks.

\section{Moderating Effect of Foreign Ownership on Bank Stability and Ownership Structure}

Study runs a regression analysis to determine the moderating effect of foreign ownership structure on the relationship between bank stability and the financial performance of commercial banks. The equation for the interaction was;

$$
\mathbf{Y}=\boldsymbol{\beta}_{\mathbf{0}}+\boldsymbol{\beta}_{1} \text { (Foreign Ownership * Bank Stability) }+\boldsymbol{\beta}_{\mathbf{2}}(\text { Foreign Ownership })+\boldsymbol{\varepsilon}
$$

Table 13. Model Summary of Foreign Ownership Structure and Bank Stability

\begin{tabular}{lcccc}
\hline Model & $\mathrm{R}$ & $\mathrm{R}$ Square & Adjusted R Square & Std. Error \\
\hline Without & & & & \\
Moderator & $.734^{\mathrm{a}}$ & .539 & .525 & 1.83089 \\
With Moderator & $.856^{\mathrm{b}}$ & .733 & .720 & 1.71017 \\
\hline
\end{tabular}

a. Predictors: (Constant), CAMEL

b. Predictors: (Constant), CAMEL, Foreign Ownership Structure

Source: SPSS output 
In line with the above results in Table 13, the regression model summary indicates that bank stability without the moderating variable explains $53.9 \%\left(\mathrm{R}^{2}=.539\right)$ variations in the financial performance of commercial banks. With the moderating variable factored in the effect improves to $73.3 \%\left(\mathrm{R}^{2}=.733\right)$. This implies that the foreign ownership structure has a positive effect on the relationship between bank stability and the financial performance of commercial banks in South Sudan. Abdallah, Amin, Sanusi, and Kusairi (2014) also indicated that foreign ownership of commercial banks had a positive effect on the financial performance of commercial banks in South Sudan.

Table 14. ANOVA Summary for Foreign Ownership Structure and Bank Stability

\begin{tabular}{llccccc}
\hline Model & & Sum of Squares & df & Mean Square & F & Sig. \\
\hline Without & Regression & 395.280 & 1 & 131.70 & 39.306 & $.000^{\mathrm{a}}$ \\
moderator & Residual & 338.567 & 4 & 3.352 & & \\
& Total & 733.848 & 5 & & & \\
With & Regression & 321.99 & 1 & 160.600 & 54.912 & $.000^{\mathrm{b}}$ \\
Moderator & Residual & 411.858 & 2 & 2.925 & & \\
& Total & 733.848 & 3 & & & \\
\hline
\end{tabular}

a. Dependent Variable: Financial Performance

b. Predictors: (Constant), CAMEL, Foreign Ownership Structure

Source: SPSS output

Results of the ANOVA summary sought to examine the statistical significance of the moderating effect of foreign ownership structure on the relationship between bank stability and the financial performance of the commercial banks. The F-statistic with the moderator variable was 54.192 which is greater than the f-critical value. The significance of the model was $\mathrm{p}=.000<.005$. This shows that the coefficients in the model were not equal to zero and the model was fit.

Table 15. Regression Coefficient for Foreign Ownership and Bank Stability

\begin{tabular}{|c|c|c|c|c|c|c|}
\hline \multirow{2}{*}{\multicolumn{2}{|c|}{ Model }} & \multicolumn{2}{|c|}{$\begin{array}{l}\text { Unstandardized } \\
\text { Coefficients }\end{array}$} & \multirow{2}{*}{$\begin{array}{c}\text { Standardized } \\
\text { Coefficients } \\
\text { Beta } \\
\end{array}$} & \multirow[b]{2}{*}{$\mathrm{t}$} & \multirow[b]{2}{*}{ Sig. } \\
\hline & & $\mathrm{B}$ & Std. Error & & & \\
\hline \multirow[t]{2}{*}{1} & (Constant) & 9.370 & 3.215 & & 2.915 & .006 \\
\hline & CAMEL & .583 & .091 & .637 & 5.291 & .000 \\
\hline \multirow[t]{3}{*}{2} & (Constant) & -1.431 & 2.672 & & -.536 & .595 \\
\hline & CAMEL & .303 & .067 & .399 & 4.505 & .000 \\
\hline & $\begin{array}{l}\text { Foreign } \\
\text { Ownership }\end{array}$ & .784 & .112 & .620 & 7.003 & .000 \\
\hline
\end{tabular}

a. Dependent Variable: Financial Performance

Source: SPSS output

Findings of the study in Table 15, showed the regression coefficients results for the moderating effect of joint venture ownership on the relationship between bank stability and financial performance. Coefficient of the interaction was .784 with a p-value of $.000<.005$. With the above significance in the coefficient of foreign ownership bank stability, this implied that foreign ownership significantly moderated the relationship between bank stability and financial performance of commercial banks.

\section{Conclusion and Recommendation}




\section{Conclusions}

Findings of the study indicated that CAMEL components had a statistically positive effect on the financial performance of commercial banks. The study concludes that strengthening the CAMEL components can foster the soundness of commercial banks in South Sudan. The research further concludes that commercial banks should ensure there is regular examination of the CAMEL components to ensure the institution meets the optimal CAMEL model rating scores. The study found that a unit increase in foreign ownership would lead to increase in financial performance of commercial banks. The study concludes that from a regulatory standpoint the CBSS should come with new policy changes that are geared towards improving the financial status of public-owned and private local banking institutions to limit the growing dominance of foreign institutions and joint venture firms.

\section{Recommendations}

This study recommends that there is need for commercial banks to improve their performance in terms of their ROEs and ROAs. There has been a general erratic behaviour in the performance on these two specific ratios and it is clear that the overall performance has been sliding down; hence banks should undertake measures that will counter any negative impact on their overall financial performance. The study further recognizes that the nascent development of the banking institutions within the South Sudan sector has been noticed by the Bretton woods institutions. The study recommends that through bilateral engagements the Central Bank of South Sudan could engage the IMF and World Bank experts in designing better statutory policies as well as seeking extended cushion reserves injection that will help in expanding the growth and operation of indigenous banking institutions.

In respect to the ownership levels of commercial banks, the study notes that the South Sudan banking industry has come of age has witnessed by the increasing proliferation of foreign banking institutions within the sector. The study recommends that the regulator should develop a comprehensive policy that will guide the setting up of foreign banking institutions in the country. The study recommends that due to their advanced capabilities and growth foreign banking institutions should be compelled to shed part of their equity to local individual investor or institutional investor to develop a sense of ownership within the country. Further, the government should develop policies that will support local banking institutions to be able to comprehensively compete with larger foreign-owned banks.

\section{References}

1) Abera, A. (2012). Factors Affecting Profitability: An Empirical Study on Ethiopian Banking Industry. Addis Ababa University.

2) Abdallah, Z. M., Amin, M. A., Sanusi, N. A., \& Kusairi, S. (2014). Impact of Size and Ownership Structure on Efficiency of Commercial Banks in Tanzania: Stochastic Frontier Analysis. International Journal of Economic Perspectives, 8(4), 66.

3) Akhigbe, A., McNulty, J. E., \& Stevenson, B. A. (2017). Does the form of ownership affect firm performance? Evidence from US bank profit efficiency before and during the financial crisis. The Quarterly Review of Economics and Finance, 64, 120-129.

4) Al Mamun, M. A. (2013). Performance evaluation of prime bank limited in terms of capital adequacy. Global Journal of Management and Business Research., 13-21.

5) Beck, T., Hesse, H., Kick, T., \& Westernhagen, N. (2009). Bank Ownership and Stability: Evidence from Germany.

6) Elewechi, R. M. (2007). Corporate Governance in Nigeria: The Status Quo. . Corporate Governance: An International Review , 15(2), 173-193. 
7) Fang, Y., Hasan, I., \& Marton, K. (2014). Institutional development and bank stability: Evidence from transition countries. Journal of Banking \& Finance, 39, 160-176.

8) Fauzi, H., \& Idris, K. (2013). The Relationship of CSR and Financial Performance: New Evidence From Indonesian Companies. The American Economic Review, 2(1), 58-79.

9) FSNWG. (2015). East Africa Crossborder Trade Bulletin Volume 9. Food Security and NutritionWorking Group and Market Analysis Subgroup.

10) IMF. (2017). 2016 Article IV Consultation-Press Release: Staff Report; and Statement by The Executive Director for Sudan. International Monetary Fund.

11) International Monetary Fund. (2014). Republic of South Sudan: Article IV. IMF.

12) Kothari, C. R. (2004). Research Methodology: Methods and Techniques. New Delhi: : New Age International (P) Ltd.

13) Kothari, C. R. (2011). Research methodology: methods and techniques. New Age International.

14) Kotler, P., \& Armstrong, G. (2013). Principles of Marketing (14th ed). London: Pearson Prentice Hall.

15) Mohiuddin, G. (2014). Use of CAMEL model: A study on financial performance of selected commercial banks in Bangladesh. Universal journal of accounting and finance, 2(5), 151-160.

16) Nimalathasan, B. (2008). A comparative study of financial performance of banking sector in Bangladesh. An application of CAMELS rating system. Universitatii Bucuresti. Analele. Seria Stiinte Economice si Administrative, 2, 133.

17) Ndoka, S., Islami, M., \& Shima, J. (2017). The impact of liquidity risk management on the performance of Albanian Commercial Banks during the period 2005-2015. International Journal of Social Sciences and Education Research, 3(1), 70-76.

18) Pearce, J. A., \& Robinson, R. B. (2011). Strategic Management: Strategy Formulation, Implementation, and Control (12th ed). Chicago, IL: R. D.: Irwin, Inc.

19) Robert, C., Maria, S., Martinez, P., \& Jeanne, V. (2017). Bank Ownership: Trends and Implications. IMF Working Paper.

20) SSIC. (2013). South Sudan's Financial Sector. South Sudan Investment Conference.

21) Tripathi, D., Meghani, K., \& Mahajan, S. (2014). Financial Performance Of Axis Bank And Kotak Mahindra Bank In The Post Reform Era: Analysis On CAMEL Model. ssrn papers.

22) Yener, A., \& David, M. (2008). Mergers and acquisitions and bank performance in Europe: The role of strategic similarities. Journal of Economics and Business, Volume 60, Issue 3; Pages 204-222. 